certain peculiar features which suggest that all these remains belong to one family-or to several families united by common descent." "Thus three of six crania possess large and uncommon Wormian bones." Professor Stuart Pigott says this about the bones from Lanhill Long Barrow (Wilts) : "It was possible to show that the nine individuals were members of one particular family group, recognizable not only by the striking similarities in features, but also in the presence of the rare Wormian ossicles in seven of the nine skulls." 3

Anatomists and radiologists, on the other hand, have not been categorical about the alleged familial incidence of Wormian bones. Indeed they appear to have shown little interest in the problem.- I am, etc.,

Pontypridd,

W. K. E. BERNFELD.

Glamorgan.

REFERENCES

Keith, A., J roy. anthropol. Inst., 1913, 13, 86.
ibid., 1913, 13, 89.
Pigott, S., and Daniel, G. E., The Neolithic Cul-
tures of the British Isles, 1954. Cambridge Unitures of the $B$ tit
versity Press.

\section{Corticosteroid Eye-drops}

SIR,-I enclose the instructions and information pamphlet of an eye ointment which is said to contain $0.5 \%$ neomycin, $1 \%$ pimaricin, and $1 \%$ hydrocortisone. The makers advise: "In Ophthalmology : Indicated in the treatment of infections caused by bacteria, fungi or yeasts and of allergic affections of the eyelids and anterior segment of the eye. 'Pimafurcort' must be applied into the conjunctival sac 2-4 times a day."

In the Scientific Exhibition at the Annual General Meeting of the Irish Medical Association in $1963 \mathrm{I}$ exhibited a large series of photographs which showed cases of herpessimplex ulceration which failed to heal over periods of many months and in some cases caused perforation of the cornea, requiring corneal grafting; in each case ulceration was due to the abuse of steroids. I also showed cases of corneal abscess, some due to fungi, not. all of which recovered useful vision, although in some it was possible to save the eye. Again the infection was partly due to the abuse of corticosteroids. These dangerous side-effects in the eye have been known for many years and are now well established. -I am, etc.,

$$
\text { Galway, Eire. G. Everard Hewson. }
$$

\section{Consanguineous Marriage}

SIR,-Dr. Aleck Bourne's interesting letter (21 December, p. 1590) rightly points out the great importance of Ruffer's paper on the lack of deleterious effects of incestuous marriage in the ancient Egyptian royal line. It is perhaps unfortunate that Dr. Bourne should have included the controversial figure of the Pharaoh Akhenaten in his argument, since the latter was certainly physically abnormal. Cyril Aldred and I have discussed at length the problems posed in Egyptology and pathology by this fascinating personage. $^{2}$ Modern assessments of the king's character are less ecstatic than those of Breasted, who regarded him as a "brave soul," "the world's first idealist," and " the most remarkable figure of the Ancient World before the Hebrews." We have pointed out also that much of the glory has departed from his much-publicized domestic idyll with Nefertiti ; Newberry commented on Akhenaten's intimate relationship with his son-in-law Smenkh-ka-re, which recalls the notorious liaison of the Emperor Hadrian with the youth Antinous.

The physical appearance of Akhenaten as shown in colossi and reliefs has evoked much argument. Early Egyptologists were uncertain whether the ancient sculptors were depicting a king or a queen. Mariette wondered if Akhenaten had been taken prisoner in the Sudan and there castrated. ${ }^{5}$ Lefébure considered that Akhenaten may have been a woman masquerading as a man, pointing out that Queen Hatshepsut had previously usurped Pharaonic power. ${ }^{\circ}$ Pendlebury described one of the Karnak colossi as a "wonderful pathological study."”

Further controversy arose when Theodore M. Davis discovered in the Valley of the Kings a tomb (now numbered 55); excavation revealed a handsome wooden coffin containing a skeleton. This was thought at first to be female but later was shown to be that of a male apparently about 25 years of age. Weigall believed that the bones were those of Akhenaten, ${ }^{8}$ but an obvious difficulty arose since we know that Akhenaten must have been at least 30 years of age when he died.

Considerations of space forbid detailed discussion, but it seems likely that Akhenaten had some endocrine disorder exemplified by obesity and hypogonadism. This was possibly the result of a pituitary adenoma. The hypogonadism would have delayed epiphyseal closure, so that the remains found in Valley Tomb No. 55 could indeed be those of Akhenaten. An inevitable consequence of this hypothesis would be incapacity of Akhenaten to father his putative children. As his father, Amenophis III, was for a long period co-regent with him, it is possible that Amenophis was their sire.

(I have recently been informed by Cyril Aldred that Professor H. W. Fairman, of the School of Archaeology and Oriental Studies at Liverpool, has arranged a reexamination of the remains from Valley Tomb No. 55. It is greatly to be hoped that the examining team of experts will include a pathologist with experience of endocrine disorders, since the views of academic anatomists alone are scarcely sufficiently informed in the special problems of this field to produce a final and definite answer to this much-vexed question.)

Secondly, with regard to Cleopatra VII one can only agree with Dr. Bourne that her fatal fascination was not the result of great physical beauty; the famous relief from Dendera shows a hook-nosed woman with obese upper arms and a fullness of the throat which suggests that she may have been goitrous.-I am, etc.,

Glasgow W.2.

\section{A. T. SANDison.}

REFERENCES

Ruffer, M. A., Proc. roy. Soc. Med., 1919, 12 Aldred, C., and Sandison, A. T., Bull. Hist.

Breasted, J. H., in Cambridge Ancient History, 1924. Voi. 2, p. 109

- Newberry, P. E., F. Egypt. Archaeol., 1928, 14, 7 Mariette, A., Buil. archaeol., 1855, 1, 57.
Lefébure, E., Proc. Soc. biblical Archaeol., 1890 $91,13,479$. Pendlebury, J. D. S., Tell-el-Amarna, 1935 Lovat Dickson and Thompson, London Weigall, A., The Life and Times of Akhnaton, Pharaoh of Egypt, 1922. Thornton Butterworth

\section{Paediatric Prescribing}

SIR,-I should like to make two comments on drugs mentioned in the To-day's Drugs article on paediatric prescribing (14 December, p. 1519).

Perhaps the most useful way of using aminophylline in general practice is as a suppository. Oral aminophylline causes vomiting and is not to be recommended. The rectal dose is 3 to $5 \mathrm{mg}$. per pound (7-11 $\mathrm{mg} . / \mathrm{kg}$.) body weight. The adult suppository may be suitably divided, and the sharp edges pared off before insertion.

It is difficult to justify the paragraph on antispasmodics. Atropine methyl nitrate has been shown by many people to be a useful drug in pyloric stenosis. Its use in whoopingcough is in my opinion dangerous, because its action is to dry up the secretions which are thus made more difficult to cough up. The "spasm" of coughing is, of course, due to increased sensitivity of the respiratory mucous membrane, and has nothing whatever to do with spasm of smooth muscle. A logical and effective treatment in whooping-cough is to administer large doses of phenobarbitonefor example, $\frac{1}{2}$ gr. (32 mg.) eight-hourly-even in a small baby. Sufficient sedation should be given to control the paroxysms, combined with postural drainage before feeds to ensure that any mucus present is removed. The younger the patient the more important sedation becomes, because the danger lies in petechial haemorrhages in the brain caused by the venous songestion and anoxia associated with a prolonged coughing bout.- $\mathrm{I}$ am, etc.,

General Hospital,

Plymouth.

\section{J. N. MONTGOMERY.}

\section{Tests for Occult Blood}

SIR,-Some time ago in a leading article in the British Medical fournal ${ }^{1}$ our attention was drawn to the fact that in gastric carcinoma-and in varying degree also in neoplasm anywhere in the alimentary tractonly about one-third of all cases are referred immediately to hospital by the general practitioner. The point is no less relevant to-day.

Responsibility for the earliest diagnoses of alimentary ulceration, whether malignant or benign, will always lie with the general practitioner. The symptoms are often vague and protean in their manifestations, and it is not practicable to send every case for $x$-ray investigation. In the early stages $x$-ray findings may be negative or inconclusive. Since, however, occult blood is present in the faeces of a large proportion of these cases (Meulengracht and Jensen ${ }^{2}$ found occult blood present in $89 \%$ of a series of 105 alimentary neoplasms confirmed by operation or necropsy) a simple and reliable consultingroom test for faecal occult blood can be of the greatest value in the early detection not only of alimentary neoplasm but also of peptic ulcer. This is much more prevalent than was once realized. ${ }^{3}$

Regarding tests for occult blood it is of interest that in their recent paper Dr. L. $\mathrm{H}$. Blumgart and Mr. D. J. Bowen (21 December, p. 1572) demonstrated that ferrous fumarate did not cause intestinal bleeding, as has been reported-and also confirmed that the widely used and now widely taught "hematest" and "occultest" tablets are not altogether satisfactory. 